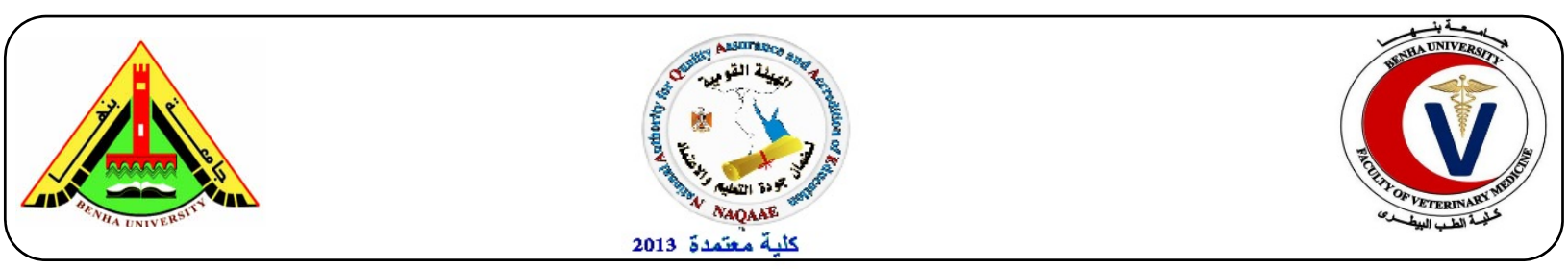

\title{
Bacteriological assessment of Street Vended Meat Products sandwiches in kalyobia Governorate
}

Fahim Aziz-Eldin Shaltot, Mohamed, A.H. El-Shater ${ }^{2}$, Wafaa Mohamed Abd El-Aziz

${ }^{1}$ Food Hygiene Dep., Fac. Vet. Med., Benha Univ. ${ }^{2}$ Animal Health Research "Doki". ${ }^{3}$ Animal Health Research "Benha branch".

\begin{abstract}
A B S T R A C T
Contamination of ready-to-eat foods sold by street vendors rendering them unacceptable for human consumption and become a global health problem. This study aimed to examine the quality and safety of street vended meat products in kalyobia governorate. Eighty samples of meat products including 20 samples each of beef burger, kofta, sausages and hawawshi were randomly collected from the streetvendors in kalyobia governorate to evaluate their bacteriological quality. The results revealed that the mean values of APC, Enterobacteriaceae, coliform and staphylococcus counts (cfu $/ \mathrm{g}$ ) were $3.97 \times 10^{5}$, $5.82 \times 10^{3}, 6.53 \times 10^{2}$ and $2.76 \times 10^{3}$ for burger, $8.51 \times 10^{5}, 7.15 \times 10^{3}, 9.25 \times 10^{2}$ and $5.41 \times 10^{3}$ for kofta, $1.33 \times 10^{6}, 9.91 \times 10^{3}, 4.38 \times 10^{3}$ and $1.23 \times 10^{4}$ for sausage, $6.76 \times 10^{6}, 4.07 \times 10^{4}, 1.12 \times 10^{4}$ and $6.11 \times 10^{4}$ for hawawshi respectively. Also Staph. aureus were isolated with an incidence of $40 \%, 45 \%, 55 \%$ and $70 \%$ ( with mean value of $7.54 \times 10^{2}, 8.13 \times 10^{2}, 1.96 \times 10^{3}$ and $4.28 \times 10^{3} \mathrm{cfu} / \mathrm{g}$ ) from the examined samples of burger, kofta, sausage and hawawshi, respectively. Also the incidences of isolation of E.coli from the same examined samples were $10 \%, 15 \%, 25 \%$ and $30 \%$, respectively. The obtained results were compared to the published microbiological guidelines for RTE food of center of food safety(2014) to assess their bacteriological quality and It was recommended that this guidelines may be adapted locally(for RTE Egyptian food) until more precise microbial criteria for this food type could be developed through an appropriate scientific process.
\end{abstract}

Key words: Street Vended, cooked, Meat Products, Staph. aureus, E. Coli.

(http://www.bvmj.bu.edu.eg) conference issue

(BVMJ-28(2): 58-66, 2015)

\section{INTRODUCTION}

$\mathrm{S}$ treet-vended foods are ready-to-eat foods prepared and sold by vendors on streets and similar public places. They provide a source of readily available, inexpensive and nutritional meals, while providing a source of income for the vendors (Swanepoel et al., 1998). Despite the economic and nutritional benefits of street foods, the consumption of these roadside foods has been suggested to potentially increase the risk of food borne diseases as street foods are readily contaminated from different sources (Tambekar et al., 2008). It has been shown that Street-vended foods have been implicated in outbreaks of foodborne illnesses all around the world (CNN, 1999).
In Egypt, street vended food especially meat products may represent a hazard due to the bad condition at which it produced in as using raw materials of poor quality, inadequate personnel hygiene of vendors and holding for long period lead to contamination of food with pathogenic microorganism. Such contamination may render the product of inferior quality or unfit for human consumption (Gundogan et al., 2005). The presence of specific microorganisms such as E.coli, Staph. aureus and Salmonella in foods served by the street vendors is an indicative of a degree of ignorance on the part of the handlers towards proper hygienic practices (Lues et al., 2006). Also the major sources 
contributing to microbial contamination are the place of preparation, utensils for cooking and serving, raw materials, time and temperature abuse of cooked foods and the personal hygiene of vendors (RaneSharmila, 2011). In recent years, E.coli has become recognized as a serious food borne pathogen and has been associated with numerous out breaks of disease (Scotter et al., 2000). Staphylococcus aureus have been implicated in cases of severe diarrhea as well as that is the main cause of food poisoning gastroenteritis among consumers (Davies and Board, 1998). In Egypt, there is no available data concerning the incidence of food-borne diseases related to street food and paucity of information on the quality and safety of street-vended food, and where effective food safety controls by concerned regulatory agencies are yet to be realized, evaluation of the street food microbial hazards and their indicators would help providing criteria for setting functional bacteriological guideline values. Therefore, this study was conducted to assess the microbial quality of street vended meat product sandwiches (including beef burger, kofta, sausage and hawawshi) in kalyobia Governorate and to highlight the public health implication of consuming such food products.

\section{MATERIAL and METHODS}

\subsection{Collection of samples:}

80 random samples of street vended meat products including burger, kofta, sausage and hawawshi (20 of each) were collected from street vendors in Kalyobia governorate. Each sample was kept in a separate sterile plastic bag, put in an icebox then transferred to the laboratory under complete aseptic conditions without undue delay for bacteriological examination.

\subsection{Bacteriological examination}

\subsubsection{Preparation of samples (APHA, 2001):}

Twenty five grams of the meat products samples were taken under aseptic condition to sterile stomacher bag then $225 \mathrm{ml}$ sterile $0.1 \%$ peptone water were added, the contents were homogenized at Stomacher for 2 minutes, the mixture was allowed to settled, for 5 minutes at room temperature. The contents were transferred into sterile flask, thoroughly mixed, $1 \mathrm{ml}$ was transferred into separate sterile test tube containing $9 \mathrm{ml}$ sterile $0.1 \%$ peptone water, from which tenth- fold serial dilutions were prepared. The prepared samples were subjected to the following bacteriological examination:

\subsubsection{Determination of Aerobic Plate} Count (ICMSF, 1996). Determination of Enterobacteriaeae count (ISO, 2004). Coliform count using Violet Red Bile agar medium (ICMSF, 1996). Determination of Staphylococci and Staph. aureus count using Baired Parker agar (FDA, 2001). Isolation \&identification of E.coli (APHA, 1992). It was applied by using Macconkey broth as enriched broth and EMB as plating media. Serological Identification: The isolates were identified serologically by using rapid diagnostic E.coli antisera sets (DENKA SEIKEN Co., Japan) for diagnosis of the pathogenic types according to (Kok et al., 1996). Isolation of Staph. aureus According to (ICMSF, 1996)

\section{RESULTS}

It is evident from the results recorded in table (1) that the mean values in the examined samples of street vended burger, kofta, sausage and hawawshi were $3.97 \times 10^{5}, 8.51 \times 10^{5}, 1.33 \times 10^{6}$ and $6.76 \times 10^{6}$ $\mathrm{cfu} / \mathrm{g}$ for APC, respectively; $5.82 \times 10^{3}$, $7.15 \times 10^{3}, 9.91 \times 10^{3}$ and $4.07 \times 10^{4} \mathrm{cfu} / \mathrm{g}$ for Enterobacteriaceae count, respectively ; $6.53 \times 10^{2}, \quad 9.25 \times 10^{2}, 4.38 \times 10^{3}$ and $1.12 \times 10^{4} \mathrm{cfu} / \mathrm{g}$ for coliform count, respectively and $2.76 \times 10^{3}, 5.41 \times 10^{3}$, $1.23 \times 10^{4}$ and $6.11 \times 10^{4} \mathrm{cfu} / \mathrm{g}$ for total staphylococcal count, respectively. In other words, there is a highly significant difference of APC, enterobacteriaceae, coliform and Staphylococcal counts between the examined products. $(P<$ 
0.01).Based on the microbiological guidelines of ready-to-eat food (CFS, 2014), it is cleared that out of 80 examined samples of street vended meat products $6.25 \%$ were of unsatisfactory quality due to their APC as obtained in table (2)., Meanwhile $21.25 \%$ of the examined samples were of unsatisfactory quality due to their enterobacteriaceae counts as declared in table (3). It is evident from the result recorded in table (4) that Staph. aureus were isolated with an incidence of $40 \%$ (with a mean value of $7.54 \times 10^{2} \mathrm{cfu} / \mathrm{g}$ ), $45 \%$ (with a mean value of $8.13 \times 10^{2} \mathrm{cfu} / \mathrm{g}$ ), $55 \%$ (with a mean value of $1.96 \times 10^{3} \mathrm{cfu} / \mathrm{g}$ ) and $70 \%$ (with a mean value of $4.28 \times 10^{3} \mathrm{cfu} / \mathrm{g}$ ) from the examined samples of burger, kofta, sausage and hawawshi, respectively. There is a highly significant difference of Staph. aureus count between the examined product . $(P<0.01)$. Results in table (5) declared that $52.5 \%$ of the total examined samples fell in the category borderline according to their $S$. aureus count based on the mictobiological guidelines of RTE food (CFS, 2014). Results achieved in Table (6) indicated that the incidence of $E$. coli in the examined burger samples was $10 \%$ and the isolated strains were $\mathrm{O}_{55}$ : H7and $\mathrm{O} 119: \mathrm{H} 4$, while in kofta samples it was $15 \%$ and the isolated strains were O127:H6 and O111:H4, also it was $25 \%$ in the examined sausage samples and the isolated strains were $\mathrm{O} 111: \mathrm{H} 4, \mathrm{O} 55$ : $\mathrm{H} 7$ and $\mathrm{O} 26: \mathrm{H} 11$. While in hawawshi was $30 \%$ and the isolated strains were $\mathrm{O} 26: \mathrm{H} 11, \mathrm{O}_{55}: \mathrm{H} 7$, O86 and $\mathrm{O} 124$.

Table (1): Mean values of bacterial profile (CFU/g) in the examined samples of street vended meat products $(\mathrm{n}=20)$.

\begin{tabular}{|c|c|c|c|c|}
\hline Items & Burger & Kofta & Sausage & Hawawshi \\
\hline $\begin{array}{l}\text { Aerobic plate } \\
\text { count }\end{array}$ & $3.97 \times 10^{5}$ & $8.51 \times 10^{5}$ & $1.33 \times 10^{6}$ & $6.76 \times 10^{6}$ \\
\hline $\begin{array}{l}\text { Enterobacteriaceae } \\
\text { Count }\end{array}$ & $5.82 \times 10^{3}$ & $7.15 \times 10^{3}$ & $9.91 \times 10^{3}$ & $4.07 \times 10^{4}$ \\
\hline $\begin{array}{l}\text { Coliform } \\
\text { Count }++\end{array}$ & $6.53 \times 10^{2}$ & $9.25 \times 10^{2}$ & $4.38 \times 10^{3}$ & $1.12 \times 10^{4}$ \\
\hline $\begin{array}{l}\text { Staphylococcal } \\
\text { Count ++ }\end{array}$ & $2.76 \times 10^{3}$ & $5.41 \times 10^{3}$ & $1.23 \times 10^{4}$ & $6.11 \times 10^{4}$ \\
\hline
\end{tabular}

$++=$ High significant differences $(P<0.01)$.

Table (2): Acceptability of the examined samples of street vended meat products according to the microbiological guidelines (CFS, 2014) for APC $(n=20)$.

\begin{tabular}{ccccccccccccc}
\hline Categories & $\begin{array}{c}\text { Range } \\
\text { Cfu/g }\end{array}$ & \multicolumn{2}{c}{ Burger } & \multicolumn{2}{c}{ Kofta } & \multicolumn{2}{c}{ Sausage } & Hawawshi & \multicolumn{2}{c}{ Total } \\
& & No & $\%$ & No & $\%$ & No & $\%$ & No & $\%$ & No & $\%$ \\
\hline Satisfactory & $<10^{5}$ & 2 & 10 & 4 & 20 & 0 & 0 & 0 & 0 & 6 & 7.5 \\
Borderline & $10^{5}-10^{7}$ & 18 & 90 & 16 & 80 & 20 & 100 & 15 & 75 & 69 & 86.25 \\
Unsatisfactory & $\geq 10^{7}$ & 0 & 0 & 0 & 0 & 0 & 0 & 5 & 25 & 5 & 6.25 \\
\hline
\end{tabular}


Table (3): Acceptability of the examined street vended meat products according to the microbiological guidelines, (CFS, 2014) for Enterobacteriaceae counts $(n=20)$.

\begin{tabular}{cccccccccccc}
\hline Categories & $\begin{array}{c}\text { Range } \\
\text { CFU/g }\end{array}$ & \multicolumn{2}{c}{ Burger } & \multicolumn{2}{c}{ Kofta } & \multicolumn{2}{c}{ Sausage } & Hawawshi & \multicolumn{2}{c}{ Total } \\
& & No & $\%$ & No & $\%$ & No & $\%$ & No & $\%$ & No & $\%$ \\
\hline Satisfactory & $<10^{2}$ & 0 & 0 & 0 & 0 & 0 & 0 & 0 & 0 & 0 & 0 \\
Borderline & $10^{2}-<10^{4}$ & 18 & 90 & 18 & 90 & 13 & 65 & 14 & 70 & 63 & 78.75 \\
Unsatisfactory & $\geq 10^{4}$ & 2 & 10 & 2 & 10 & 7 & 35 & 6 & 30 & 17 & 21.25 \\
\hline
\end{tabular}

Table (4): Statistical analytical results of total Staph. aureus count/g in the examined samples of street vended meat products $(n=20)$.

\begin{tabular}{|c|c|c|c|c|c|}
\hline \multirow{2}{*}{ Products } & \multicolumn{2}{|c|}{ +ve Samples } & \multirow{2}{*}{ Min. } & \multirow{2}{*}{ Max. } & \multirow{2}{*}{ Mean \pm S.E* } \\
\hline & No. & $\%$ & & & \\
\hline Beef burg & 8 & 40 & $1.0 \times 10^{2}$ & $2.0 \times 10^{3}$ & $7.54 \times 10^{2} \pm 1.60 \times 10^{2++}$ \\
\hline Kofta & 9 & 45 & $1.0 \times 10^{2}$ & $2.0 \times 10^{3}$ & $8.13 \times 10^{2} \pm 2.04 \times 10^{2++}$ \\
\hline Sausage & 11 & 55 & $1.0 \times 10^{2}$ & $5.0 \times 10^{3}$ & $1.96 \times 10^{3} \pm 0.37 \times 10^{3++}$ \\
\hline Hawawshi & 14 & 70 & $1.0 \times 10^{2}$ & $8.0 \times 10^{3}$ & $4.28 \times 10^{3} \pm 0.86 \times 10^{3++}$ \\
\hline
\end{tabular}

${\mathrm{S} . E^{*}}^{*}$ Standard error of mean. $++=$ High significant differences $(P<0.01)$.

Table (5): Acceptability of the examined samples of street vended meat products according to the microbiological Guidelines, (CFS, 2014) for Staph. aureus count/g $(n=20)$.

\begin{tabular}{cccccccccccc}
\hline \multirow{2}{*}{ Categories } & $\begin{array}{l}\text { Range } \\
\text { Cfu/g }\end{array}$ & \multicolumn{2}{c}{ Burger } & \multicolumn{2}{c}{ Kofta } & \multicolumn{2}{c}{ Sausage } & \multicolumn{2}{c}{ Hawawshi } & \multicolumn{2}{c}{ Total } \\
& No & $\%$ & No & $\%$ & No & $\%$ & No & $\%$ & No & $\%$ \\
\hline Satisfactory & $<20$ & 12 & 60 & 11 & 55 & 9 & 45 & 6 & 30 & 38 & 47.5 \\
Borderline & $20-\leq 10^{4}$ & 8 & 40 & 9 & 45 & 11 & 55 & 14 & 70 & 42 & 52.5 \\
Unsatisfactory & $>10^{4}$ & 0 & 0 & 0 & 0 & 0 & 0 & 0 & 0 & 0 & 0 \\
\hline
\end{tabular}

Table (6): Incidence and serotyping of E. coli isolated from the examined samples of street vended meat products $(n=20)$.

\begin{tabular}{lcccccccc}
\hline \multicolumn{1}{c}{$\begin{array}{c}\text { Product } \\
\text { E.coli }\end{array}$} & \multicolumn{2}{c}{ Beef Burger } & \multicolumn{2}{c}{ Kofta } & \multicolumn{2}{c}{ Sausage } & \multicolumn{2}{c}{ Hawawshi } \\
Strains & No. & $\%$ & No. & $\%$ & No. & $\%$ & No. & $\%$ \\
\hline O26: H11 & - & - & - & - & 1 & 5 & 2 & 10 \\
O55 : H7 & 1 & 5 & - & - & 1 & 5 & 1 & 5 \\
O86 & - & - & - & - & - & - & 1 & 5 \\
O111 : H4 & - & - & 2 & 10 & 1 & 5 & 1 & 5 \\
O119: H4 & 1 & 5 & - & - & 2 & 10 & - & - \\
O124 & - & - & - & - & - & - & 1 & 5 \\
O127 : H6 & - & - & 1 & 5 & - & - & - & - \\
Total & 2 & 10 & 3 & 15 & 5 & 25 & 6 & 30 \\
\hline
\end{tabular}




\section{DISCUSSION}

This study revealed that, sandwiches of street vended meat products had significant growth of microorganisms, but the microbial load of samples of certain products were higher than others to the extent that it may pose a threat to the health of regular consumers. Overall, data presented in table (1) revealed that the mean values of total APC of the examined samples of street vended beef-burger, kofta, sausage and hawawshi sandwiches were $3.97 \times 10^{5}, 8.51 \times 10^{5}, 1.33 \times 10^{6}$ and $6.76 \times 10^{6}$ $\mathrm{cfu} / \mathrm{g}$, respectively. The current results were nearly similar with those obtained by Ibrahim-Ghada (2001) who found that, The mean values of APC in RTE hawawshi sandwiches was $21.2 \times 10^{6} \mathrm{cfu} / \mathrm{g}$. While lower results were recorded by Sobieh (2014) found that the mean value of APC in ready to eat kofta was $1.83 \times 10^{4} \mathrm{cfu} / \mathrm{g}$ ,Also higher results were recorded by $\mathrm{Abu}$ EL Hassan-Asmaa (2012)who found that, the mean value of APC in street vended cooked sausage was $8 \times 10^{7} \mathrm{cfu} / \mathrm{g}$. Although, APC of any food articles are not a sure indicative of their safety for consumption, yet it is of supreme importance in judging the hygienic condition under which food has been produced, handled and stored (Levine, 1987). As the high incidences of bacterial contamination are mainly due to the unsanitary and largely unhygienic nature of the food preparations and services areas as foods are good indicators of the state of environment in which they are prepared or served (Ehiri et al., 2001). High APC, may indicate that the cooking process was inadequate, or post cooking contamination had occurred, or the length of time and temperature control in storage or display facilities was inadequate to prevent bacterial growth, or that a combination of these factors was involved (Khater-Dalia et al., 2013).

Enterobacteriaceae count used to assess the general hygiene status of a food product and their presence in heat treated food indicates inadequate cooking or post- processing contamination (CFS, 2014). It is also could indicates time/temperature abuse during handling or inadequate storage and displaying conditions during sale. As these microbial groups are safety indicators, the presence of high counts may indicate possible presence of pathogens (Jay, 2005). The obtained results in table (1) showed that the higher average of Enterobacteriaceae count in the examined samples of street vended meat products was recorded in hawawshi sandwiches samples $\left(4.07 \times 10^{4} \mathrm{cfu} / \mathrm{g}\right)$, while the lower one was in the examined beef burger sandwiches samples $\left(5.82 \times 10^{3} \mathrm{cfu} / \mathrm{g}\right)$. Moreover, the average of Enterobacteriaceae count in the examined samples of street vended kofta and sausage sandwiches were $7.15 \times 10^{3}$ and $9.91 \times 10^{3} \mathrm{cfu} / \mathrm{g}$. The current results were relatively agree to that obtained by Zaghloul et al. (2014) who found that the mean value of Enterobacteriaceae count in street vended burger was $31 \times 10^{2} \mathrm{cfu} / \mathrm{g}$, while higher results were recorded by Shaltout et al. (2013) who found the mean value of street vended kofta samples was $1.5 \mathrm{x}$ $10^{7} \mathrm{cfu} / \mathrm{g}$. Based on the mictobiological guidelines of ready-to-eat food (CFS, 2014) out of 80 examined samples of street vended meat products $6.25 \%$ were of unsatisfactory $\left(\mathrm{APC} \geq 10^{7}\right)$ quality due to their APC (observed only in the examined hawawshi sandwiches samples) as obtained in table (2), While $21.25 \%$ were of unsatisfactory quality due to the high level of Enterobacteriaceae count which exceeds the recommended limit (total count $\geq 10^{4}$ ) as declared in table (3).

Members of coliforms groups are referred as general indicator microorganisms to measure the potential presence of enteric pathogens in foods, besides the measuring of fecal contamination of food products and the sanitary condition in the foods processing environment (FAO, 1992). The presence of these organisms in RTE food (sandwiches) depicts a deplorable state of poor hygiene and sanitary practices employed in the processing and packaging of this food 
product (Jay, 2005). The possibility of food health problem by coliforms depending upon the number, types and the virulence of these pathogens whereas, the higher the number, the greater possibility of pathogenic organisms being present (FAO, 1992). The result declared that the mean values of total coliform counts in the examined samples of street vended beefburger, kofta, sausage and hawawshi sandwiches were $6.53 \times 10^{2}, 9.25 \times 10^{2}$, , $4.38 \times 10^{3}$ and $1.12 \times 10^{4} \mathrm{cfu} / \mathrm{g}$, respectively. the obtained results were relatively agree to some extent with those obtained by KhaterDalia et al (2013) who found that the mean value of total coliform count of RTE street vended grilled kofta was (2.92 log cfu/g), While lower results were obtained by ElMaghraby- Marwa (2014) $\left(9,69 \times 10^{2} \mathrm{cfu} / \mathrm{g}\right)$ for cooked sausage. Also higher results were recorded by Shaltout et al. (2013) (2.6 $\left.\mathrm{x} 10^{5} \mathrm{cfu} / \mathrm{g}\right)$ in the examined street vended kofta.

Staphylococcus species. are common environmental bacteria and could thus have been introduced into the food after cooking through cross contamination, for instance from utensils used by the vendors (Mosupy and Holy, 1999). Their presence in food indicates poor personal hygiene and poor manufacturing practices of the vendor (Musa and akande, 2002). It's obvious from the results obtained in table (1) that that the mean values of total staphylococcal count in the examined samples of street vended beefburger, kofta, sausage and hawawshi sandwiches were $2.76 \times 10^{3}, 5.41 \times 10^{3}$, $1.23 \times 10^{4}$ and $6.11 \times 10^{4}$, respectively. The current results are nearly similar to that obtained by Saad et al. (2011) (1.85 $\mathrm{x} 10^{3} \mathrm{cfu} / \mathrm{g}$ ) for RTE beef- burger While lower results were recorded by Masoad Nagwa (2013) $(3.8 \times 10 \mathrm{cfu} / \mathrm{g})$ for street vended kofta. Moreover higher results were obtained by Adam (2009) $\left(1.24 \times 10^{5} \mathrm{cfu} / \mathrm{g}\right)$ for street vended kofta.

The presence of Staph. aureus in heat treated food is a pointer to largely poor personal hygiene, improper storage facilities, and unhygienic environment
(Achi and Madubuike, 2007). Regarding to results illustrated in table (2), the highest incidence for isolation of Staph. aureus in the examined samples of street vended meat product sandwiches was recorded in hawawshi $(70 \%)$ followed by sausage $(55 \%)$,kofta (45\%) and beef- burger (40\%). Also Staph. aureus failed to be detected by Masoad-Nagwa (2013) from the examined street vended kofta samples, while could be isolated from meat products by Adam (2009)(10\%), Saad et al. (2011)(35\%), and Sobieh (2014) (6.67\%).In general, Staph. aureus isolates from RTE foods was more likely come from food handlers who contaminate foods (Baumgartner et al., 2014). Total Staph. aureus count can be taken as index of sanitary conditions under which the meat and its products are manufactured and handled (Potter, 2001).The obtained results in table (2) revealed that, the mean values of total Staph. aureus count in the examined samples of beef-burger, kofta, sausage and hawawshi sandwiches were $7.54 \times 10^{2} \pm$ $1.60 \times 10^{2}, 8.13 \times 10^{2} \pm 2.04 \times 10^{2}, 1.96 \times 10^{3} \pm$ $0.37 \times 10^{3}$ and $4.28 \times 10^{3} \pm 0.86 \times 10^{3} \mathrm{cfu} / \mathrm{g}$, respectively. The obtained results of Staph aureus count for the examined burger samples were comparatively similar to those obtained by Zaki -Eman (2003)(9 x $\left.10^{2} \mathrm{cfu} / \mathrm{g}\right)$, while higher results were obtained by Adam (2009) who found that the mean value of Staph. aureus count in the examined samples of street vended kofta samples was $6.14 \times 10^{3} \mathrm{cfu} / \mathrm{g}$. Based on the mictobiological guidelines of ready-to-eat food (CFS, 2014) $52.5 \%$ of the total examined samphes fell in the category borderline based on their total Staph . aureus count $\left(20 \leq 10^{4} \mathrm{cfu} / \mathrm{g}\right)$ as obtained in table (5) which carry a significant risk if applied under certain condition that help Staph. aureus to proliferate and make it to fell in the category unsatisfactory. The proliferation of Staph. aureus in food creates a potential public health hazard, considering that many strains of Staph. aureus produce enterotoxins that may cause food poisoning when ingested (Bennett et 
al., 2013). The isolation of unacceptable level of Staph. aureus count $\left(>10^{4}\right.$ as recommended by CFS, 2014), responsible for staphylococcal food poisoning revealed that street foods are sources of bio toxins that may make food injurious to health on an acute or chronic basis (Achi and Madubuike, 2007). E. coli used as an indicator microorganism because it provides an estimate of fecal contamination and poor sanitation during processing (Eisel et al., 1997). Its presence in RTE foods indicates that the food has been prepared under poor hygienic conditions (KhaterDalia et al., 2013). From the results illustrated in table (6) it's obvious that the incidences of E.coli isolated from the examined samples of street vended meat products were $10 \%, 15 \% .25 \%$ and $30 \%$ for the examined samples of beef burger, kofta, sausage and hawawshi sandwiches, respectively. E. coli was previously isolated from ready to eat meat products by Abdel Fattah-walaa(2014) and Sobieh (2014) who could isolate $E$. coli from hawawshi with an incidence of $33.33 \%$. Also data obtained in the same table (6) revealed that the isolated serotypes of pathogenic E. coli from the examined samples of beef burger sandwiches were $055: H 7(5 \%)$ and 0119 : $H 4(5 \%)$, while in examined samples of kofta 0111 : $H 4$ (10\%) and O127:H6(5\%) were identified. Moreover, in the examined samples of sausage sandwiches $\mathrm{O} 26$ : H11(5\%), O55 : H7(5\%), O111 : H4 (5\%) and O119: $H 4(10 \%)$ were identified. While in the examined samples of hawawshi sandwiches O26: H11 (10\%), O55:H7 (5\%), O86 (5\%), O111:H4 (5\%) and O124 $(5 \%)$ were identified. Such pathogenic strains of E. coli were previously isolated from different ready-to-eat meat products by Abdel Fattah-Walaa (2014) who isolated O26 (13.3\%), O111 : H4 (6,7\%) and 0127 : H6 (6.7\%) from RTE kofta samples, also isolated O26 (13.3\%), O111 : H4 (6,7\%), O119 : H4 (6.7\%) and O127 : H6(13.3\%) from hawawshi samples. In general, Heat treated foods must be free from $E$. coli (Gluck, 1995). The detection or even low number of E.coli in foods constitutes a public health hazard (ICMSF, 1980).

\section{Conclusion}

These findings demonstrate that ready-to eat street vended meat products sandwiches sold in kalyobia governorate constitutes a likely potential hazard to human health. This is due to high bacterial load and isolation of specific pathogens as Staph. aureus and E.coli Spp. at which presence of such microorganisms in RTE food constitute a significant risk and render this type of food of low quality and unfit for human consumption. In addition, the highest level of contamination of the examined samples was recorded in hawawshi samples followed by sausage, kofta and burger sandwiches. Consequently, measures to control the quality of the raw material, environmental and hygienic conditions during preparation and serving should be taken for the production of relatively safe street-vended foods with low bacterial counts. Also, Health agency personnel, vendors and consumers of the street vended food need to be informed of the hazards and appropriate preventive measures. While there is still no microbial guideline value for Egyptian RTE foods, the adoption of the published guideline values of center of food safety may be appropriately used until more comprehensive guideline values for Egyptian RTE foods are be established.

\section{REFERENCES}

Abdel Fattah -Walaa, M.G. 2014. Incidence of Salmonellae and Escherichia coli in ready to eat foods. M.V. Sc. Thesis (Meat hygiene), Fac. Vet. Med. Benha Univ.

Abu EL Hassan -Asmaa, A.A. 2012 .Trials for Improvement quality of sausage. M.V.Sc. Thesis (meat hygiene), Fac.Vet. Med., Benha. Univ.

Achi, O.K., Madubuike, C. N. 2007. Prevalence and antimicrobial Resistance of Staphylococcus aureus isolated from 
Retail ready to eat foods in Nigeria. Res. J. Microbiol., 2(6) :516-523.

Adam, H.A. 2009.Microbiological quality of street vended foods of animal origin. M.V. S.C, Thesis (Meat hygiene), Fac. Vet Med., Kafr Elshiekh Univ.

American Public Health Association "APHA" 2001. Compendium of methods for the microbiological examination of food. $4^{\text {th }}$ Ed Washington D., USA.

American Public Health Assoication "APHA" 1992. Compendium of methods for the microbiological examination of foods. $3^{\text {rd }}$ Ed. Speck, H.L. (ed.).Washington D.C. APHA.

Baumgartner, A., Niederhauser, I., Johler, S. 2014.Virulence and Resistance Gene Profiles of Staphylococcus aureus Strains Isolated from Ready-to-Eat Foods .J. Food Protect., 7:1232-1236.

Bennett, S.D., Walsh, K.A., Gould, L.H. 2013. Foodborne disease outbreaks caused by Bacillus cereus, Clostridium perfringens and Staphylococcus aureus United States, 1998 - 2008. Clin. Infec. Dis., 57:425-433.

Cable news network (CNN) 1999.Fourteen die in mass food poisoning in Cuba (News Report: 7 February 1999). CNN interactive, cnn.com.

Center for Food Safety "CFS" 2014. Microbiological Guidelines for Food (For ready-to-eat food in general and specific food items). Risk Assessment Section, Food and Environmental Hygiene Department43/F, Queensway Government Offices, 66 Queensway, Hong Kong.

Davies, A., Board, R. 1998. Microbiology of meat and poultry. A textbook, $1^{\text {st }}$ Ed. Edmunds burg Press. Ltd. Edmunds, London.

Ehirl, J.E.J., Azubuike, M.C., Ubbaonu, C.N., Anyanwu, E.G.; Lbe, K.M., Ogbonna, M.O. 2001.Critical control points of complementary food preparation and handling in eastern Nigeria. Bull World Health Organ, 79 (5): 423 - 433.

Eisel, W. G., Lintion, R. H., Muriana, P. M. 1997. A survey of microbial levels for incoming raw beef, environmental sources and ground beef in a red meat processing plant. J. Food Microbiol., 14: 273-282.

El-Maghraby- Marwa, S.M. 2014. Bacteriological evaluation of meat and some meat products at consumer level.
M.V.Sc., Thesis (Meat Hygiene), Fac. Vet. Med. Sadat City. University.

Food and Agriculture Organization " FAO " 1992.Escherichia coli and other coliforms. Manual of food quality control. Rev.1Microbiological Analysis, Food and Agriculture Organization of the United Nation, Rome, Italy, Chap. 3PP, 13-26.

Food and Drug Administration "FDA" 2001. Staphylococcus aureus. Bacteriological analytical manual $.8^{\text {th }}$ Ed. Chapter12. Gaithersburg, p.562.

Gluck, Claudia 1995. Global Quality Manual, Publisher Gate Gournet International, Zurich.

Gundogan, N., Citak, S.,Yucel, N., Olkkonen, L. ,Devren, A. 2005. A note on the incidence and antibiotic resistance of Staphylococcus aureus isolated from meat and chicken samples. J. Meat Sci., 69:807810.

Ibrahim-Ghada, M. M. 2001.Ready-to-eat sandwiches as a source of Potential Pathogen in Assuit city. M. V. Sc., Thesis (Meat Hygiene), Fac. Vet. Med., Assiut Univ.

International commission of Microbiological Specification for Foods "ICMSF" 1996. Microorganisms in Food. I-Their Significance and methods of enumeration. $3^{\text {rd }}$ Ed. Univ. of Toronto, Canada.

International Commission on Microbiological Specification for Foods "ICMSF" 1980. Microbiological ecology of foods. Vol. I. Factors affecting life and death of microorganisms. Academic Press, New York, London, Sydney.

International Organization for Standardization " ISO " 2004 .No. 11291-1. Microbiologiy of food and animal feeding stuffs Horizontal methods for detection and enumeration of Enterobacteriaceae part 2: colony count method.

Jay, J. M. 2005 .Modern Food Microbiology 4th Ed. Chapman and Hall, New York.p.187.

Khater- Dalia, F., Heikal, G. E., Shehata, A.A., El-Hofy, F. I. (2013): The Microbiological Assessment of Ready-To-Eat-Food (Liver and Kofta Sandwiches) In Tanta City, Egypt. Benha Vet. Med. J., 25(2):187-197.

Kok, T., Worswich, D., Gowans, E. 1996.Some serological techniques for microbial and viral infections. I n Practical Medical Microbiology (Collee, J.; Fraser, A.; 
Marmion, B. and Simmons, A., eds.), $14^{\text {th }}$ ed., Edinburgh, Churchill Livingstone, UK.

Levine, M.M. 1987. Escherichia coli that cause diarrhea: enterotoxigenci, enteropathogenic, enteroinvasive, enterohaemorrhagic enteroaldherant. J. Infect. Dis. 155:377-389.

Lues, J.F.R., Rasephei, M. R., Venter, P., Theron, M. M. $2006 . \quad$ Assessing food safety and associated food-handling practices in Street food vending. Int. J. Environmental Health Research, 16(5):319-328.

Masoad-Nagwa, S. 2013 .Staphylococcal food poisoning associated with fast foods. M. V. Sc. Thesis, Meat Hygiene, Fac. Vet. Med. Benha Univ.

Mosupye, F.M., Holly, A. 1999. Microbiological quality and safety of ready-to-eat street vended foods in Johannesburg. South Africa. J. Food Prot. 62, 11: 1278.

Musa, O.L., Akande, T.M. 2002. Effect of Health Education Intervention or Food Safety Practice among Food Vendors in Ilorin. J. Med. 5:120 - 124.

Potter, N.N. 2001.Food Science. $3^{\text {rd }}$ Ed. The AVI Publishing Co., INC. New York, USA.

Rane-Sharmila. 2011. Street vended food in developing world: hazard analyses. Indian J. Microbiol., 51(1):100-106.

Saad M.S., Hemat, M.I., Enas, A.M. 2011. Microbial and chemical evaluation of fast foods. J. Benha vet. Med. S.E (1):4451.
Scotter, S., Aldridge, M., Capps, K. 2000. validation of method for the detection of E.coli O157:H7 in foods. Food Control, 11: 85-95.

Shaltout, F.A., Amani, M.S., Mahmoud, A.H., Abd Elraheem, K.A. 2013.Bacterial aspect of cooked meat and edible offal at street vendors level. J. Benha vet. Med. 24(1):320-328.

Sobieh, A.S. 2014.Fast meat meals at restaurant level in Cairo Governorate. M. V. Sc. Thesis, Meat Hygiene, Fac. of Vet. Med. Benha Univ.

Swanepoel, F.J., Hobbs, C., Becker, P.J. , Ijsselmuiden, C. 1998. The quality of food sold by traders in central Johannesburg and factors associated with contamination. J. Compr. Health 6:188-190.

Tambekar, D.H., Jaiswal, V.J., Dhanorkar, D.V, Gulhane, P.B., Dudhane, M.N. 2008. Identification of microbiological hazards and safety of ready-to-eat food vended in streets of Amravati City,India. J. Appl. Biosciences., 7: 195 - 201.

Zaghloul, R.A., El-Shenawy, M.A., Neweigy, N.A., Abou-Aly, H.E.; El-dairouty, R. K., El-Kholy, W. I., Fouad, M .T., Soriano, J. M., Mañes, J., Micó, L. 2014.Listeria spp. and Enterobacteriaceae Group in Sandwiches of Meat and Meat Products . British. Microbiol. Res .J. 4(4) 360 -368.

Zaki- Eman, M. 2003. Risk assessment of ready prepared meat products. Ph. D. Thesis, Meat Hygiene. Fac. Vet. Med., Cairo University. 